\title{
エチレン処理した ‘土佐ブンタン’果実の香気成分および 遊離アミノ酸の変化
}

\author{
西川和孝・岡林秀典*・沢村正義**・後藤昌弘***・前田英雄 \\ 鳴門教育大学学校教育学部・* 高知県農業技術センター・**高知大学農学部・*** 高知女子大学生活科学部
}

Volatile Constituents and Free Amino Acids in Ethylene-Treated Citrus grandis [L.] Osbeck Fruits

\begin{abstract}
Kazutaka NishiKawa, Hidenori OKabayashi, ${ }^{*}$ Masayoshi SawamUra, ${ }^{* *}$ Masahiro Goto*** and Hideo MAEDA

Faculty of Education, Naruto University of Education, Naruto 772-8502, Japan

* Kochi Prefectural Agriculture Research Center, Nankoku 783-0023, Japan

** Faculty of Agriculture, Kochi University, Nankoku 783-8502, Japan

*** Faculty of Human Life and Environmental Science, Kochi Women's University, Kochi 783-8515, Japan
\end{abstract}

(Received September 18, 2001)

'Tosa-buntan' (Citrus grandis [L.] Osbeck) fruits were treated with 0, 20, and $40 \mathrm{ppm}$ ethylene for $96 \mathrm{~h}$ in the dark in order to ripen the fruit and improve the color. As a result, the 20 and $40 \mathrm{ppm}$ ethylene-treated fruits showed a decrease in their chromatic component ( $L$ value), and an increase in their $a$ value and free amino acids (especially, asparagine and glutamic acid), compared with the untreated fruits. The effectiveness of ethylene treatments showed no difference between 20 and $40 \mathrm{ppm}$. Volatile constituents were analyzed by capillary GC and GC-MS, respectively. The amount of flavor compounds in the fruits showed no change regardless of the administration of the ethylene treatment or the storing period. The content of nootkatone, the characteristic flavor compound of pummelo, increased in all treatments. These results suggest that the ethylene treatment of 'Tosa-buntan' is a useful storing method for shipment to the market.

Keywords: Citrus grandis, ethylene, free amino acids, 'Tosa-buntan,' volatile constituents

2001 年 9 月 18 日受付

\section{緒}

ブンタンは，日本，中国，タイ等で栽培されている． 特に“土佐ブンタン’は, 高知県の特産果実で特有の芳 香を有する品種であり, 野囲いと呼ばれる屋外(露地) 貯蔵方法（1３力月間）によって出荷されている. 野 囲いは，園地内に穴を掘りその中にビニルシートで包
む方法であり，労力を要しないが追熟に要する貯蔵期 間が長い (Sawamura and Kuriyama, 1988)。一方，同 じく高知県の特産果実である ‘水晶ブンタン’はエチレ ン処理によるカラーリングおよび追熟予措・貯蔵が行 われている (Nishikawa et al., 2002)。そこで本研究で は, 収穫後の ‘土佐ブンタン’ の品質（着色, 追熟扔よ び食味等）向上を目的にエチレン処理法の可能性を検 討した。 ‘土佐ブンタン’は糖や酸の個体差が大きく, 果

Corresponding author: Kazutaka Nishikawa, fax : +81-88-687-6022, e-mail : nishikw@ naruto-u.ac.jp 
実の食味や品質に及ほすエチレン処理効果を評価する 上で, 食味基準として供試材料の糖や酸の含量をそろ えることが困難であることから, 果皮の色調, 香気成 分および遊離アミノ酸の変動を指標とした。

\section{材料および方法}

\section{1. 材 料}

2000 年 12 月 20 日に高知県土佐市戸波の果樹園よ り収穫したものの中から, 着色初期の ‘土佐ブンタン’ （平均果重 $700 \mathrm{~g}$ 程度）果実を用いた。

\section{2. エチレン処理}

3 台のインキュベーター（サンヨー社製 MIR-252, $\left.28^{\circ} \mathrm{C}\right)$ にそれぞれ収穫直後の供試果実 40 果を入れ, 工 チレン処理を施した. エチレン処理濃度は 0 (無処理 区), 20 および $40 \mathrm{ppm}$ とした.これらの濃度となるよ うにエチレンガス流出器（岩谷産業社製）をインキュ ベーターに装着後, ガスを 96 時間通気した。 通気した 空気中のエチレン濃度に関しては, ガスクロマトグラ フ $(\mathrm{GC}$; 島津社製 $\mathrm{GC}-15 \mathrm{~A}$, 活性アルミナカラム : $60 \sim 80 \mathrm{mesh}, 3 \mathrm{~mm}$ i.d. $\times 2 \mathrm{~m}, 60^{\circ} \mathrm{C}$, 検出器: FID) $に$ て 8 時間毎に測定および調節した (Yoshimura et al., 1996 ; Ishimaru et al., 1999).

\section{3. 果実の果皮色測定}

調査果実は各区からそれぞれ 15 果とし,色彩色差計 （ミノルタ社製 CR-300）を用いて果実の赤道部同一位 置（1 果につき 4 力所均等位置）の $L, a, b$ 值を測定 し, 測定後直ちに再び各インキュベーター内に貯蔵し た.

\section{4. 遊離アミノ酸分析}

供試果実は $0 ， 30 ， 60 ， 90$ 日目に各処理区からそれ ぞれ 5 果を採取し, 遊離アミノ酸および精油成分分析 の測定に用いた。果皮を除いた果肉部をフードプロ セッサーで細切りにし, 冷却条件下 $\left(5^{\circ} \mathrm{C}\right)$ にてホモジ ナイザーで 1 分間磨砕した。得られた果実ペースト 30 $\mathrm{g}$ にクエン酸リチウム緩衝液 $30 \mathrm{ml}$ を加え, 40 分間擋 拌した. その後, $5000 \mathrm{rpm}, 20$ 分間遠心分離し, 上澄 みを $0.45 \mu \mathrm{m}$ のフィルターに通しアミノ酸分析の試 料とした (Furudate and Meguro, 2001)。標準夜とし て, 和光純薬工業製のアミノ酸混合標準液 AN II およ びB 型にグルタミンおよびアスパラギンを加えたも のを使用した。アミノ酸分析は日本電子製アミノ酸 オートアナライザーJLC-300 型でアミノ酸生体分析カ ラム (JEOL, No. 844-350869) を用いて行った。

\section{5. 精油成分分析}

遊離アミノ酸分析で用いた各 5 果から, Sawamura and Kuriyama（1988）の方法により ‘土佐ブンタン’の 冷圧油（cold-pressed oil : CPO) を調製し, GC (島津 社製 GC-14A, FID）により定量分析を行った。GCの 条件は以下のとおりとした. カラム：DB-WAX キャ ピラリーカラム $(0.25 \mathrm{~mm}$ i.d. $\times 60 \mathrm{~m}, 0.25 \mu \mathrm{m}$ film thickness), カラム温度: $70^{\circ} \mathrm{C}(2 \mathrm{~min}) \rightarrow 2^{\circ} \mathrm{C} / \mathrm{min} \rightarrow$ $230^{\circ} \mathrm{C}(20 \mathrm{~min})$, 試料気化室温度: $250^{\circ} \mathrm{C}$, 検出器温 度：250 $\mathrm{C}$, キャリアーガス:窒素, ガス流量：1.0 ml/ min. また, 上記の GC 条件で GC-MS (島津社製 GC17A/QP-5000)による定性分析も行った（Mitiku et al., 2000).

\section{結果および考察}

エチレン処理による ‘土佐ブンタン’ 果皮色の経時的 変化を Table 1 に示した.果皮色の明度を示す $L$ 值は, 無処理区では貯蔵期間中ほとんど変動しなかったが, エチレン処理区では減少傾向となった. 緑色〜赤色を 示す $a$ 值は全処理区において増加傾向であり, その值 はエチレン処理区がわずかに高まった。一方, 青色〜黄 色を示す $b$ 值は貯蔵期間中すべての処理区において 増加傾向であり, 無処理区がわずかに高まった. $a$ 值お よび $b$ 值とも $20 \mathrm{ppm}$ および $40 \mathrm{ppm}$ のエチレン濃度 処理間では差がなかった。これまで‘水晶ブンタン’で は, エチレン処理によって果皮色の $L$ 值および $a$ 值が 高く, $b$ 值が微増することが知られているが (Nishikawa et al., 2002), 本実験の ‘土佐ブンタン’では, エ チレン処理によって果皮色にほとんど変動はなかっ た.この両品種の違いは‘土佐ブンタン’果皮色に関す る代謝のエチレン感受性が鈍いことによると考えられ るが, 一方でエチレン処理時に果皮色の $a$ 值および $b$ 值がそれぞれ-6および 59 前後と高く，すでに供試材 料果皮の黄化が進んでいたことを示しており，このこ とが処理効果の十分に現れなかった要因とも推定され る.

“土佐ブンタン’果実は，マイルドな芳香を有するこ とが特徴の一つである。そこで, エチレン処理濃度お よび貯蔵期間別における果実のフレーバー組成の経時 的変化を調べた。果皮の $\mathrm{CPO}$ から, 30 種類の香気成分 を同定した(Table 2). そのうち，テルペン系炭化水素 類はリモネン, ミルセン, $\alpha$-ピネン等の 17 種類であっ た. 他にはカンキツ類の特徵的なフレーバーを示すと 考えられる含酸素化合物のアルデヒド類（n-オク夕 

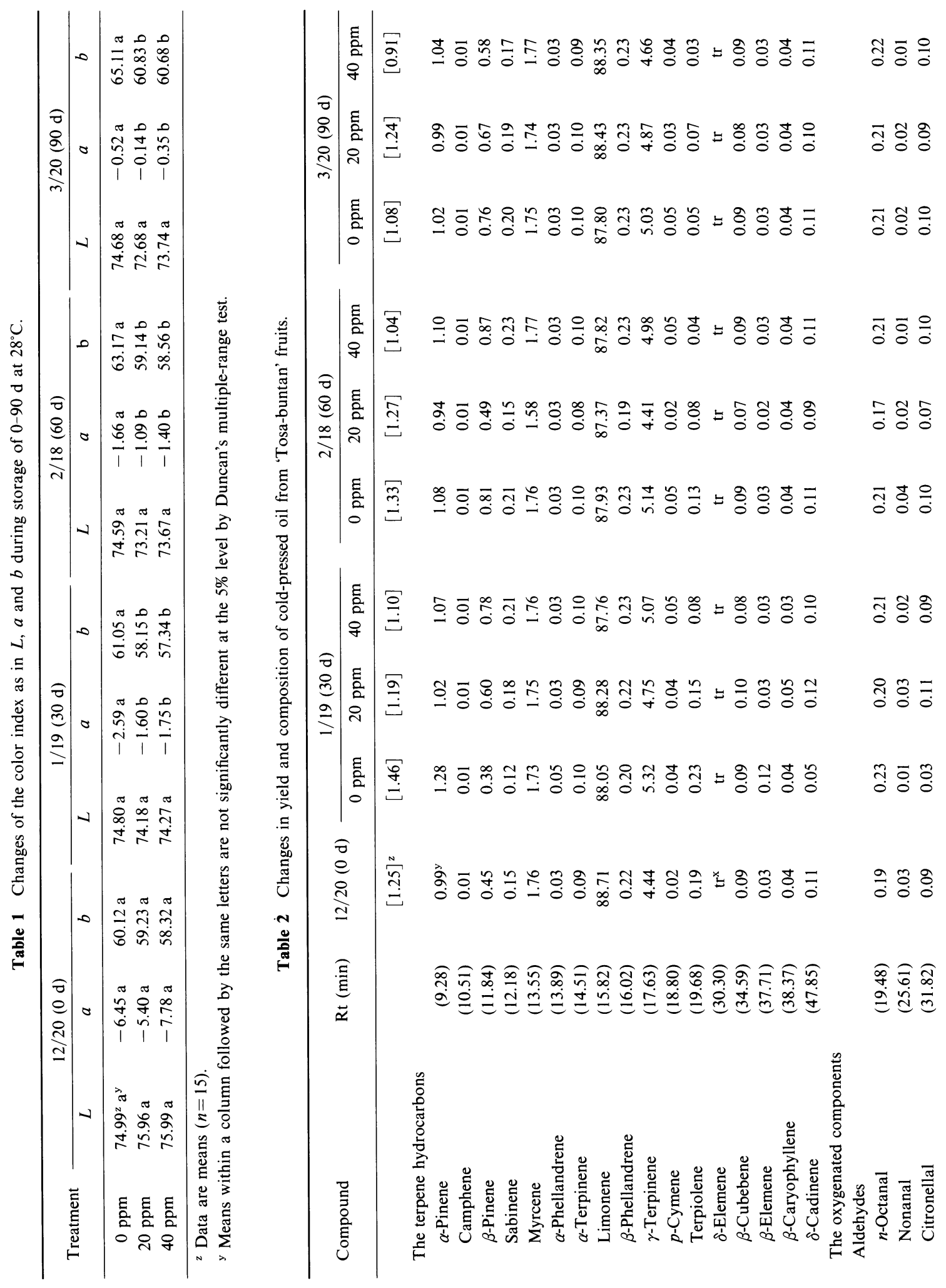


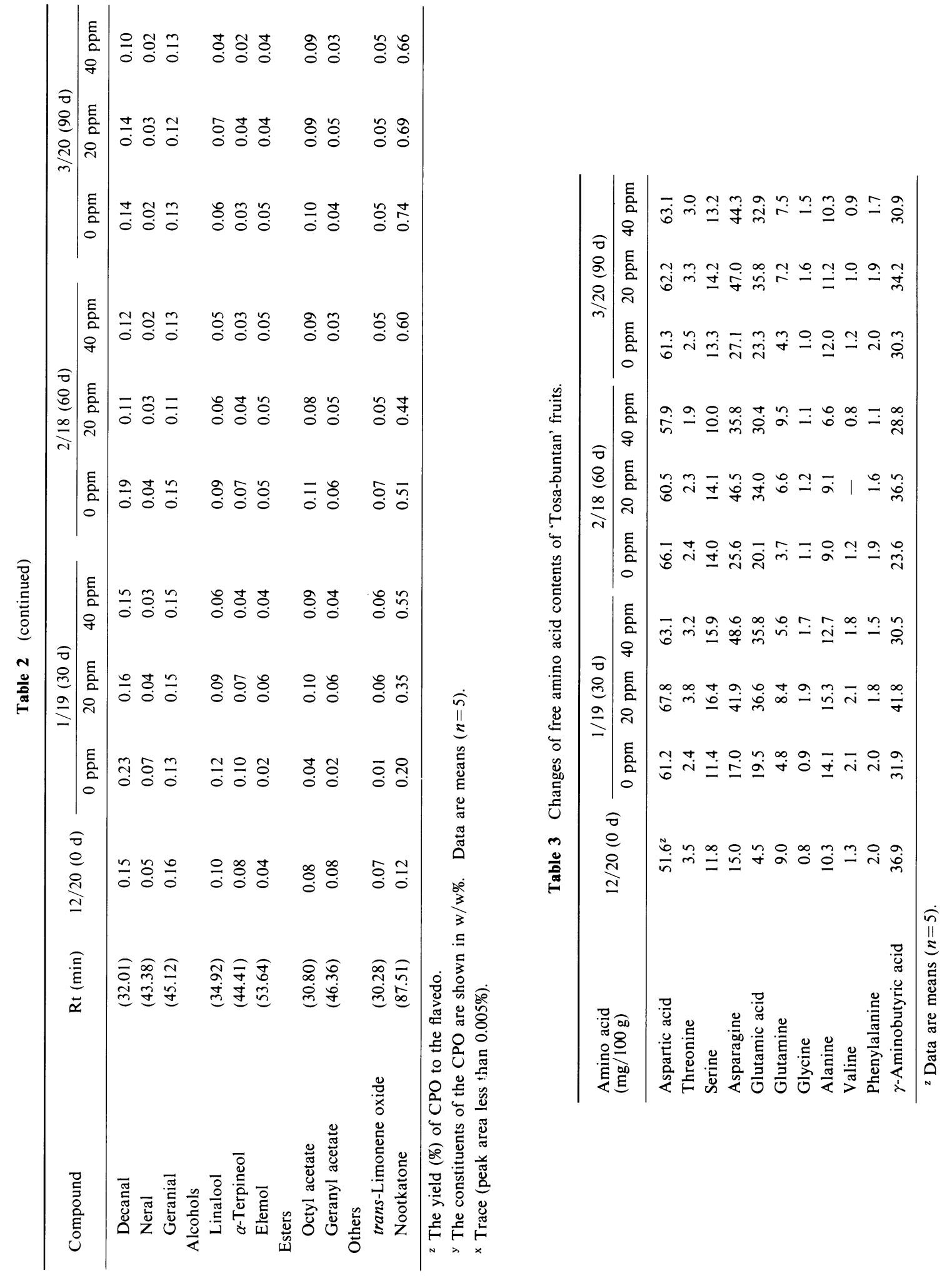


ナール, デカナール等の 6 種類), アルコール類(リナ ロール， $\alpha$-テルピネオール，エレモールの 3 種類）お よびエステル類 (オクチルアセテート, ゲラニルアセ テートの 2 種類）等が検出された. フレーバーの主成 分はカンキツ類に共通に含有されるリモネンであり, エチレン処理濃度に関係なく貯蔵期間を通して 87.37〜88.71\%の高含量であった。また, ブンタン類果 実の特徴的な成分である $n$-オクタナール (0.17〜 $0.23 \%)$, デカナール $(0.10 \sim 0.23 \%)$, リナロール $(0.04 〜$ $0.12 \%)$ およびシトロネロール（0.03～0.11\%) もまたエ チレン処理濃度に関係なく, 貯蔵期間中大きな変動は みられなかった. 一方, 同じくブンタン類の特徵的成 分であるヌートカトンはすべての処理区において貯蔵 90 日後では，5〜6 倍程度増加した (Table 2). 上述し たことは, Sawamura et al. (1989) の生産現場での貯 蔵（野囲い）における調査結果と一致していた。“土佐 ブンタン' 果実のその他の成分, すなわち香気成分組成 および CPO (\%) もエチレン処理の有無および貯蔵期 間の長短によってほとんど変化がなかった (Table 2). 以上の結果, 油胞中の揮発性成分の代謝はエチレン処 理に影響されないのではないかと推定される。

つぎに，エチレン処理濃度および貯蔵期間別におけ る果実汁中の遊離アミノ酸含量について Table 3 に示 した。果実汁中に 11 種類の遊離アミノ酸が検出され た。収穫時の主なアミノ酸は，アスパラギン酸 (51.6 $\mathrm{mg} / 100 \mathrm{~g}), \gamma-ア ミ ノ$ 酪酸 $(36.9 \mathrm{mg} / 100 \mathrm{~g})$ およびアス パラギン $(15.0 \mathrm{mg} / 100 \mathrm{~g})$ であった。貯蔵 30 日目では, エチレン無処理区のアスパラギンおよびグルタミン酸 含量がそれぞれ $17.0 \mathrm{mg} / 100 \mathrm{~g}, 19.5 \mathrm{mg} / 100 \mathrm{~g}$ である のに対し, エチレン処理区の前者が $41.9 \sim 48.6 \mathrm{mg} / 100$ $\mathrm{g}$, 後者が $35.8 \sim 36.6 \mathrm{mg} / 100 \mathrm{~g}$ とそれぞれ高含量を示
した.また,貯蔵 60 日目以降も同様の傾向がみられた. 旨味に関与するアミノ酸には, グルタミン酸, グルタ ミン, アスパラギン酸等があり, 特にグルタミン酸は 微量でも核酸系の旨味成分との相乗効果が知られてい る (Furudate and Meguro, 2001).このように, ‘土佐 ブンタン'果実へのエチレン処理によって旨味に関与 するアミノ酸が増加したことから, 商品価值が上がる ため ‘水晶ブンタン’ と同様に ‘土佐ブンタン’ へのエチ レン処理の有効性を見いだすことができた。

\section{文献}

Furudate, A., Meguro, T. 2001. Free amino acids in poteto tubers and their extraction by boiling water. J. Home Econ. Jpn. 52 : 71-74.

Ishimaru, M., Yamamoto, T., Morioka, Y., Ueda, Y., Chachin, K. 1999. Effects of continuous exposure to $100 \% \mathrm{CO}_{2}$ and its gradual reduction to $0 \%$ on ethylene production in Japanese persimmon 'Tonewase' fruit. J. Jpn. Soc. Hortic. Sci. 68 : 890896.

Mitiku, S. B., Sawamura, M., Itoh, T., Ukeda, H. 2000. Volatile components of peel cold-pressed oils of two cultivars of sweet orange (Citrus sinensis (L.) Osbeck) from Ethiopia. Flavour Fragr. J. 15 : 240-244.

Nishikawa, K., Okabayashi, H., Mitiku, S. B., Sawamura, M. 2002. Bitter and volatile compounds in ethylene-treated Citrus grandis [L.] Osbeck fruits. J. Jpn. Soc. Hortic. Sci. 71 : 292-296.

Sawamura, M., Kuriyama, T. 1988. Quantitative determination of volatile constituents in the pummelo (Citrus grandis Osbeck forma Tosa-buntan). J. Agric. Food Chem. 36 : 567-569.

Sawamura, M., Tsuji, T., Kuwahara, S. 1989. Changes in the volatile constituents of pummelo (Citrus grandis Osbeck foma Tosa-buntan) during storage. Agric. Biol. Chem. 53 : 243246.

Yoshimura, K., Abe, K., Chachin, K. 1996. Effect of ethylene treatment on the occurence of bitterness in different parts of partially processed carrot. J. Jpn. Soc. Cold Preserva. Food 22 : 205-209. 